\title{
"Amongst the Most Important of the Agencies": \\ Materializing "Nature" at \\ the American Lunatic Asylum
}

Linnea Kuglitsch

In the summer of 1859, a letter arrived at the Eastern Lunatic Asylum in Williamsburg, Virginia. The sender - Mr. James Majetts, who lived in a small town located in Southampton County, about 50 miles south of the asylum - had written Dr. John M. Galt, superintendent of the institution in need of professional advice (Majetts 1859). Over the previous months, a series of troubling changes in personality and habit had befallen his 27-year-old son. Alongside an increasingly abusive temper and "an irreverent attitude towards the bible," Majetts (1859: 4) reported that his son, Walter, had declared his ability to "tame any animal, wild or otherwise ... if he can come in sight of [it] ... [and] by beckoning [or] talking to it ... [and] make it follow him or do anything he may ask it." These concerns had peaked as Walter began trying to catch and tame water moccasins, a species of venomous snake native to the region, as well gathering their eggs to bring them home to hatch. 


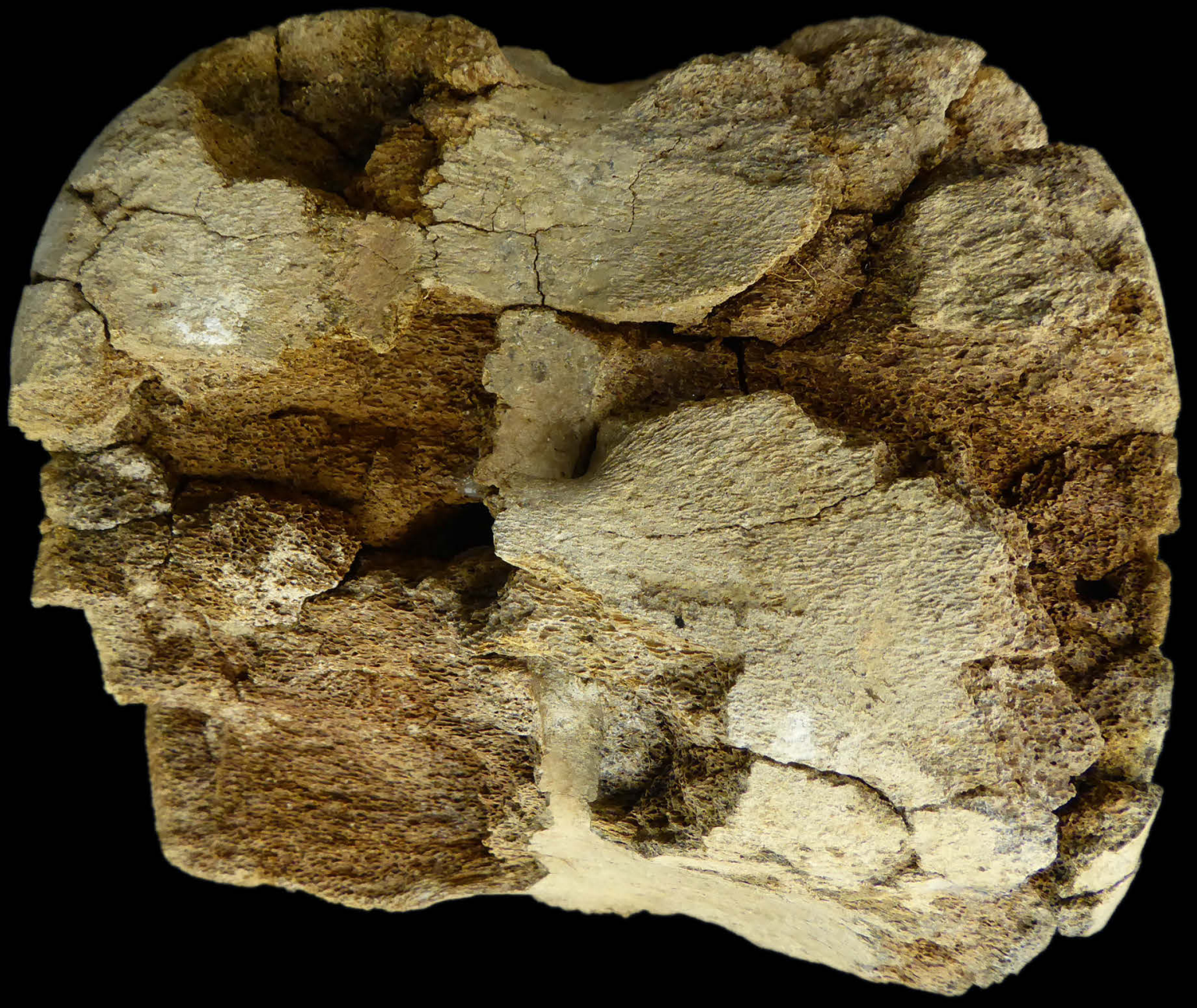


Whether this young man found a place in the Eastern Lunatic Asylum is unclear. His father's detailed account of his behavior, however, highlights the underexplored intersection of mental illness, the natural world, and curative measures in the history of psychiatry. Historians in this field have written at length about how socio-medical discourses about 'nature' and the 'natural world' informed the treatment of mental illness in the I9th and early 2oth centuries. These analyses draw on official documents like medical diaries and annual reports - records that reflect the desires and motivations of the institutional authorities who wrote and compiled them, but which neglect the perspectives of the patients they treated. While historians like Claire Hickman (2013) acknowledge that the 'natural' spaces at these institutions - that is, the lawns, gardens, fields, and other outdoor spaces integrated into the curative regime - sometimes evoked unexpected or undesirable responses among the patients who engaged with them, the maps and reports that inform these interpretations offer little insight into how patients themselves experienced or related to these landscapes. To achieve a more complete understanding of how nature and institutional life converged in the past thus requires a novel methodological approach.

This chapter explores how treatment practices centered around the natural world shaped patient life in two of American asylums: the Eastern Lunatic Asylum, which operated in Williamsburg, Virginia from I773 until I885, and the Western Washington Hospital for the Insane, which opened in Steilacoom, Washington in I87I (Dain I971; Hollander 1982). While these institutions differed in their geographic and cultural contexts, both operated according to the curative framework known as moral treatment or management. No single definition of or formula for moral management existed.

Instead, the practice encompassed a cluster of different therapeutic activities that were selected for their capacity to re-impose normalcy and regularity over the moral, emotional, and intellectual dimensions of the patient. Advocates of moral management called for patients' removal to the asylum estate, where the orderly environment and regulated routine of institutional life - combined with respectful, humane treatment and an assortment of recreational, occupational, and religious activities - was calculated to restore patients' ability to moderate their own thoughts and actions (Brigham I847). Moral management practice is commonly understood to decline among institutions on the eastern coast of the United States by the final quarter of the I9th century; however, it lingered on in the western territories (Wickham 2016). Thus, as late as 1908, Dr. John Semple - superintendent at 
Eastern Washington Hospital for the Insane, an institution founded in Washington in I89I as a counterpart to the Western Washington Hospital - explicitly linked the treatment of insanity to the moral treatment framework (Semple I908).

Moral treatment was entangled in the material and emotional landscapes of institutional life, both indoors and out. "Employment, amusement, diversions of various kinds," as superintendent at Eastern Washington Hospital for the Insane John Semple (I908: 5I) wrote, gave structure to the institutional life and operated as a mechanism for "teaching self-control and respect for the rights of others, inducing interest in books, music, flowers, open air exercises, regular methods of living, and [strengthening] all the agencies which tend to lead the mind in normal channels of thought" (ibid.). As Semple's description implies, the natural world constituted an indispensable resource in the quest to restore the insane to reason. As medical educator and practitioner Robley Dunglison declared several decades earlier, "exercise and amusement out of doors are amongst the most important of the agencies adopted in the treatment of insanity" (I836:37I). Outdoor activities, like agricultural work, picnics, sports, and walks, were understood to strengthen the body and exercise the mind, helping patients rebuild the willpower and self-control that moral collapse and organic disease had stripped away. Even patients unable to benefit from direct engagement with the carefully designed and curated grounds of the asylum estate were believed to benefit from visual exposure to pleasant, natural scenery, which diverted their attention from unhealthy, brooding thoughts (cf. ibid.).

Yet, as Majetts's letter to Dr. Galt reveals, the worrisome thoughts and troubling behaviors that medical and lay authorities interpreted as proof of mental disorder did not disappear at the asylum's threshold; they materialized outdoors, too. This chapter uses archaeological artifacts and documentary records to examine the dissonance between rhetoric and practice at two American institutions. Exploring the inherent contradictions of moral management practice, this chapter examines the tensions that arose around the 'natural world' of the institution. Different inhabitants of these establishments defined and used the grounds and gardens in different ways, creating an undercurrent of tension. While the superintendent and the attendants understood the natural world to be a tool of treatment, its value in this respect depended on their ability to control - and to some extents, limit - how patients engaged with these natural surroundings. Furthermore, the natural resources available to an institution did not always match the idealized descriptions put forth in historical advice literature. In such cases, the curative connection between patients and the natural world had to be fostered in inventive and unorthodox ways. 
This chapter opens with a brief introduction to historical archaeology, thereby positioning its approaches and contributions amongst extant scholarship investigating the grounds, gardens, and natural world of the asylum. It then introduces two archaeological artifacts: a fossilized whale vertebra and a sand dollar. Together, these artifacts illustrate dissonance between rhetorical ideals of moral management framework and the practical realities of operating an institution, shedding light onto the inhabitants of these historic sites and illuminating their relationship to the lawns, grounds, and gardens that surrounded them.

\section{Historical Archaeology and the Asylum}

Historical archaeology draws on both documentary and archaeological data to explore human culture and experiences in the past. Archaeological approaches use cultural remains, typically recovered through archaeological excavation and referred to as artifacts, to examine these topics. In practice, excavation involves the systematic stripping away of distinct stratigraphic layers, or contexts, which correlate to distinct historical periods, events, or processes. A context may correlate to a single, dramatic event, like the collapse of a building during a fire, or a long-term process like the steady filling of a household privy. The removal of each stratigraphic layer and its contents, however, amounts to the destruction of a site, so each context must be carefully documented and recorded in a manner that preserves these contextual relationships. In this manner, the archaeological process creates a simulacrum of the site, allowing researchers to continue exploring its history after excavations have been concluded. The artifacts enfolded in these contexts, meanwhile, enhance this history further, by highlighting the human activities that occurred when each stratigraphic layer was deposited. ${ }^{\mathrm{I}}$

This chapter draws on the materials, methodologies, and perspectives of historical archaeology to reexamine the relationship between the institution and the individual. It directs this through a lens that is familiar to at least a handful of historians of psychiatry and the asylum: that of its grounds and gardens. Many historians have considered these institutions and their surroundings as components of a larger therapeutic landscape - that is, as a location that was understood or engineered to facilitate physical, spiritual, mental, and emotional healing (Gesler 2005). Chris Philo's (2004) geographical examination of madness in England, for example, 
provides a survey of the development of facilities dedicated to the care and cure of the insane from the medieval to the Victorian era. This wide brushstroke brings the important role played by the natural world into focus - a theme that has been examined by several other scholars. In Therapeutic Landscapes, landscape historian Clare Hickman (2013) offers an overview of hospital gardens and their uses in several British institutions since I80o. This work, which illustrates how their design merged medical concepts with established garden types and forms, borrows from Sarah Rutherford (2005), whose scholarship highlights the development of institutional grounds as a specialty among garden designers. Stephanie Eastoe's (20I6) examination of the estate of the Caterham Imbecile Asylum - a I9th-century British institution for the chronic and incurable insane - medical authorities typically selected an institutional site and designed and apportioned its grounds to accommodate a number of requirements, from sanitary management to its curative effects.

The visual experience of the asylum grounds and gardens has also been examined. Institutions such as Brislington House tried to embed elements of picturesque scenery into their estates, suggesting that even passively absorbing scenery around the estate was understood to have a beneficial impact on the moral health of the patient (Hickman 2005, 2009). Steven Cherry and Roger Munting (2005) attend more closely to recreational regime that these landscapes supported. In their survey of late Victorian and early-2oth-century asylums in Britain, they examine how the institutions surroundings were apportioned, maintained, and used to facilitate patients' recovery through activities like cricket, football, and badminton. These outdoor activities operated as both a means of cure and as a mechanism for relieving the overcrowding that patients and staff endured as the residential populations of these establishments expanded in the mid-nineteenth century.

Scholars from a wide range of backgrounds thus agree that the grounds of the asylum played an important role in institutional life - yet, this vein of scholarship remains subject to the limitations that characterize many historical analyses. Roy Porter's (1985) foundational article, The Patient's View, charged historians of medicine with factoring patients' perspectives and experiences into the stories they tell. In recent years, the asylum patient has received significantly more scholarly attention. Still, historians of medicine have not followed through on this shift in perspective wholesale (Condrau 2007). This difficulty can be traced to methodological concerns about the character of the records that survive in the archives, documents disproportionately represent the perspectives of institutional officials. The biases, motivations, and incidental ignorance of the people who authored the primary source documents 
that have survived into the present day, combined with sparse preservation and selective curation, culminate in an assemblage of documents that challenges traditional historical research methods. ${ }^{2}$

Historical narratives surrounding the institutional landscape are especially vulnerable to these limitations. Hickman notes that many patients at the nineteenth-century asylums viewed the time they spent in the grounds and gardens as "a mixed experience;" yet, the patient perspective - and the perspectives of the staff tasked with caring for them - are conspicuously absent from the documents that commonly inform this genre of historical research (Hickman 2013: 5). Detailed descriptions needed to understand and picture the grounds typically originate in official reports written by the superintendent. Photographs, maps, and other visual renderings of the grounds were often commissioned by officials to promote the institution to potential patrons, or to underscore the success of the superintendent's innovative landscaping or horticultural programs. These records provide a clear picture of how institutional authorities defined these landscapes and how they wanted patients to interact with the grounds; however, the perspectives of patients and their attendants - and the daily realities that they faced - remain excluded from these documents and the narratives that they feed.

Still, many historians remain optimistic about the prospect of accessing the patient perspective. Brendan Kelly (20I6) insists that while patient voices remain at present largely unknown, they are not unknowable. Kelly recommends further methodological experimentation and interdisciplinary collaboration as a solution to the challenges that these sites and their histories present to historians. The outcomes from interdisciplinary collaboration "necessarily and irrevocably ... entwine bodies, minds, geographies and temporalities in creative, ambivalent and often conflictual ways," producing outputs that communicate complex and sometimes contradictory stories (Callard et al. 2015: 6). In historical archaeology, such dissonances are understood to improve, rather than detract from, the stories we tell about the past. Encountering incongruities between different datasets is a common occurrence in historical archaeology, an inherently interdisciplinary field which has a lot of methodological potential to offer researchers interested in these types of sites.

Archaeology examines the material world in terms of the physical, spatial, and geographical context in which it is encountered to learn about the human experience in the past. Historical archeology integrates archaeological data with documentary research, providing a more rigorous understanding of a site's history: from the processes that formed it to the meanings and relevance of the artifacts recov- 
ered from it. Philosopher of science Alison Wylie (1989) refers to the practice of combining different types of data as cabling. Following Wylie, when the historical and archaeological data are used together in research, they create a joint narrative that is ultimately more robust than one that is spun from a single dataset. Furthermore, any dissonances between the archaeological and archival datasets that do appear can be treated as an opportunity for further research, flagging up an area of inquiry that might have otherwise been overlooked. If reports from the hospital board of trustees, for example, indicate that dining room tables on the wards were set with plain, heavy-duty china, one would expect this type of tableware to occur commonly in an archaeological assemblage associated with that site. However, if excavations yield only porcelain from stylish teawares, researchers must return to the archival record to extrapolate on how and why these unexpected materials entered the archaeological record (Piddock 2007, 2009; Longhurst 2015).

The ability to juxtapose the stories told in documents and the remains of lived experience, or "the written and the wrought," too, is essential to seeing the whole picture of institutional life (D’Agostino 1995). By combining archaeological and documentary data, we are able to create a narrative that balances the evidence of lived practice and historical conditions with the equally important human stories of the past. This balancing act allows the researcher to explore both the mundane (and subsequently unrecorded) aspects of institutional life, and to better understand the lives, attitudes, and actions connected to "those of little note" - that is, the patients - in these histories (Scott 1994). Thus, by threading the physical residue of institutional life and treatment into the narrative, archaeological methods can help de-institutionalize asylum histories (Eghigian 20II).

The following sections introduce two artifacts recovered over the course of archaeological investigation of the aforementioned sites. First, I use archival materials to inform an analysis of a fossilized whale vertebra found on the grounds of Eastern Lunatic Asylum. As detailed examination suggests, this object has a unique curative role to play. My analysis of a second item - a sand dollar, recovered in an institutional dump associated with the Western Washington Hospital for the Insane - takes a more patient-centered approach, examining the unexpected movement of 'natural' materials into the controlled interior spaces of a morally managed institution. Adopting the methods and perspectives of historical archaeology, it becomes clear that the rhetorical ideals of moral management did not always translate into practice - particularly in the context of institutions tasked with balancing moral, sanitary, medical mores with the daily management of hundreds of patients. 


\section{Natural History at the Eastern Lunatic Asylum}

The Eastern Lunatic Asylum (hereafter, the Asylum) was established in Williamsburg, Virginia in I773. Over the first sixty years of its operation, the Asylum functioned as a custodial institution - feeding, clothing, and confining the mentally ill, but offering little in the way of effective treatment. With the popularization of moral management in the United States in the early I9th century, the need to bring the Asylum in line with professional and public values became clear to its Board of Directors. In 1839, the board of directors announced their plans to reform the institution to better accommodate the practices, landscape, and values of the moral management movement. Two years later, Dr. John M. Galt was hired on as the first superintendent of the asylum (Zwelling 1985). Credited with introducing several reforms to this institution - from fitting barren patient rooms with chairs, tables, bedsteads, and bedding, introducing occupations like shoemaking, knitting, and carpentry, to establishing a patient library - Galt's superintendence is generally regarded as the zenith of moral management at the Asylum.

Galt, like his contemporaries, regarded the institutional grounds as a powerful resource for restoring his patients' sanity. "There is no medical authority," Galt (I854: 5I) wrote, "who does not attach great importance to [the] locality [of an asylum], destined as it is to exert a continuous impression on the insane. An asylum is all the better for being provided with beautiful walks, purling streams, flowery parterres, orchards, groves, [and] beautiful views." The grounds of the Asylum never reached the level of sophistication that Galt envisioned, offering little in the way of babbling streams or scenic parterres over the course of his two-decade tenure as superintendent. They did, however, offer a pleasant setting for evening walks, carriage rides, and games of battledore. Both male and female patients made use of the enclosed lawns and gardens; a handful of male patients were even permitted to take trips into the nearby woods to walk, fish, and collect nuts (ibid.).

As the I9th century progressed, however, bringing patients into contact with the natural world through the Asylum grounds became increasingly difficult. This was due in part to the physical situation of this institution. Most mid-century lunatic asylums were established in rural locations, which provided ample opportunities for outdoor entertainment and employment that would draw patients out into the healing influence of the natural world. In comparison, when first established, the Asylum existed on periphery of the city of Williamsburg (Dain I97I: 4). By the time Galt 
became superintendent in I84I, the area surrounding the Asylum had been built up, exacerbating another imperfection of the establishment: lack of land.

The Asylum campus was minute by the standards of the era. An I835 Report to the Virginia House of Delegates described the Asylum as situated on "four acres of land in a pleasant part of the city of Williamsburg, to which is attached about two acres of land" (Garland I835: I). In I843, these holdings increased to about twenty acres with the purchase of a small farm located several miles outside of the city (Dain 197I: 9I). The Association of Medical Superintendents of American Institutions for the Insane (I885: 25) - a medical organization founded in I844, which focused on improving asylum management and patient treatment - recommended that every institution of this kind possess no less than 50 acres of land, with an additional Ioo acres for every 200 patients it served. As a founding member of the Association, Galt was intimately aware that the Asylum's twenty-acre tract was insufficient to ensure its ever-growing patient population be exposed to the healing powers of the natural world.

In I862, Dr. Galt died. His demise marked the decline of moral management practice at the asylum. By the end of the American Civil War in I865, this institution had returned to delivering custodial care. In I885, a fire destroyed the asylum buildings. This disaster, the rapid abandonment of the buildings, and the levelling of their burned-out shells left a substantial material footprint and preserved the archaeological contexts that the disaster created. Archaeological exploration of the asylum was initiated by Ivor Noel Hume in the I970s and continued intermittently throughout the second half of the 2oth century. Hume and his successors produced a wealth of data and artifactual evidence, recovering items ranging from curtain weights and mouth harps to bottles from the dispensary (Myzk I983; Hume I996). Reanalyzing these materials - now curated as a legacy collection at Colonial Williamsburg - in 20I7, one artifact stood out for its peculiarity and its resonance with the natural world. Weighing in at nearly six pounds and measuring just over six inches across, the fossilized whale vertebra recovered from the Asylum's cellar may seem out of place in an assemblage dominated by the mundane and the medical (fig. I). When viewed through the lens of the archival record, however, its significance becomes clear.

Information gleaned from historical documents associated with the asylum provides valuable context for exploring the significance of this particular artifact. Dorothea Dix, prominent advocate for asylum reform in the United States, visited the Eastern Lunatic Asylum on several occasions over the course of Galt's superin- 
tendence. The correspondence between Miss Dix and the superintendent's sister, Sarah Marie Galt, demonstrates the significance of this unusual artifact. After her brother died, Sarah Galt continued to exchange letters with Dix. In several of these, Sarah Galt (I863: 3) refers to the "almost-museum of rare shells [and] curiosities" that her brother kept in the cottage they shared on the Asylum's grounds. These "natural anomalies from foreign lands," she explained, were used as a part of the therapeutic regime during Galt's tenure; combined with Galt's "ever-agreeable innervation and explanation[s]" of their significance, this collection of objects - including the archaeologically-recovered fossilized vertebra - was used to withdraw patients "from their insane delusions" (ibid.).

While the Asylum lacked the physical resources needed to heal its patients through direct exposure to the natural world, Galt's small collection of curios helped pull patients from their moral decline. Engaging patients with artifacts reminiscent of the principles of natural history thus brought them into contact with the natural world in a novel way, acting as a mechanism for 'making do' with the Asylum's limited acreage and crowded surroundings. The rational discussions and friendly visitations that they facilitated, Sarah recounts, operated "with great success in soothing the agitated feelings \& rousing the torpid intellect" (Galt I869: I).

\section{Natural Artifacts at the Western Washington Hospital for the Insane}

In contrast to the Asylum, the Western Washington Hospital for the Insane (hereafter referred to as the Hospital) boasted a substantial estate of upwards of 400 acres throughout the late igth and early 2oth centuries. Opened in the remains of Fort Steilacoom as the Lunatic Asylum of Washington Territory, the institution capitalized on its natural surroundings from the very beginning. From the mid-I870s, patients enjoyed the use of this institution's "magnificent park;" they played baseball and football, attended dances, swam, and went walking, berry picking, fishing, and riding under its "grand and lofty shade-trees" (Hospital for the Insane I877: I). In I 887 the site was formally dedicated to the hospital. This event was marked by the construction of a new, purpose-built structure to replace the worn-down garrison buildings as well as the creation of new opportunities for outdoor employment. Male patients were put to work landscaping the grounds, maintaining the buildings, and caring for the gardens, orchards, and livestock. Female patients worked 
in the greenhouses, harvested small fruits and vegetables, and gathered seeds and wildflowers from the groves and prairies around them (Waughop I887: 20; Goldsmith/Reed I9I2: 25). By the early 20th century, outdoor activities were a well-established part of the Hospital's daily routine.

In 20I6, construction activities to install a fence on the old campus of the Hospital disturbed a dense layer of historic artifacts buried about a meter under the surface of the ground. Salvage excavations recovered a dumpsite associated with the hospital dating to around the turn of the 2oth century. In one of the earliest deposits, the fragmentary remains of Dendraster excentricus - a species of sea urchin known as a sand dollar - were recovered (Jovilette et al. 20I6). While Dendraster is native to the pacific northwest, its presence in an institutional dumpsite nearly a mile inland from its natural habitat makes it worthy of further consideration. Similarly, unlike the other bones, shells, and botanical remains present in the hospital assemblage, sand dollars are not edible. Their cultural value relates to their whimsical appearance, instead (Allman/Rubio 20I3).

The lace-like pattern on the anterior side of the animal - combined with the ease of locating and recovering them from the shoreline when washed ashore after rough weather - made these items attractive to the region's growing population of natural history collectors (Whittemore I885: 192; Merrill 1989). Specimens of Dendraster and other species of sand dollar were so popular, in fact, that they could be purchased through advertisements in specialist magazines like The Oölogist (I889) and The Museum (1895). The specimen recovered from the Hospital dump, however, does not seem to have been acquired through this avenue. The goods sold through these magazines were delivered by mail, meaning suppliers had to dry, bleach, and otherwise preserve their goods to prevent them from decaying in transit. The Hospital sand dollar, however, does not appear to have been treated in this way. Considered alongside the archival record, these material details suggest another narrative: one in which a patient visiting the nearby shoreline noticed the interesting little sand dollar, collected it, and carried it back to the Hospital, where an attendant or other institutional employee ultimately intercepted and disposed of it.

Situated on the prairie overlooking an inlet of the Puget Sound known as Chambers Bay, the Hospital was located about a mile east of the nearest shoreline. A natural depression in the landscape - known among staff and inmates of the institution as the gulch - cut through the steep bluffs that separated the Hospital from the shore and provided a convenient thoroughfare. Hospital patients and staff made frequent trips to the shoreline: as early as I88I, for example, an attendant and 
several patients were expected to hike along the gulch to the streetcar line that ran along the Bay to collect and deposit the Hospital's mail (Cooley 1964: 23). Returning from their outdoor excursions, patients regularly tried to smuggle any interesting or useful objects they encountered during their outdoor excursions onto the wards. Attempts to carry items ranging from scraps of rope to whole evergreen boughs were met with varying success, and many were intercepted by shrewd and observant attendants (Waughop I894: II). Small objects were the most difficult for hospital staff to notice and confiscate; in one case, a male patient managed to smuggle "a very harmless looking piece of sheep's rib ... picked up in one of his daily walks" to his room (ibid.:II-I2). Measuring just under eight centimeters wide and no thicker than a centimeter, the sand dollar was similarly unobtrusive - perfectly-sized to carry back indoors after a walk, tucked into a pocket or beneath an item of clothing.

\section{Constructing, Deconstructing, and Materializing 'Nature' at the Lunatic Asylum}

Examined through the lens of the documentary record, artifacts discussed above highlight a fundamental tension between the perceptions and practices surrounding nature's curative influence. Returning to the point made by Semple, inducing patients' interest in elements of the natural world, from flowers to open-air exercises and regular methods of living, could produce improvements in patients' moral and physical health (Semple I908: 5I). As researchers like Hickman (2005) and Rutherford $(2003,2005)$ suggest, this perspective was typical of the rhetoric surrounding moral management. The natural world played an important role in the curative regime of the morally managed institution. Its buildings were carefully designed and sited, and its grounds engineered, apportioned, and maintained to maximize the curative benefits of the natural world. Yet, the relationship between the institution and the natural world was more complex, as becomes clear upon transposing the archaeological remains that correlate to the activities and practices that surrounded the institutional experience of the 'natural world' over these documentary accounts. Despite their shared reliance on moral management, the Asylum and the Hospital related to their grounds - and thus the 'natural world' - differently.

Dr. John Galt's small collection of natural curiosities at the institution was kept with the intention of applying them with therapeutic effect. While viewing and discussing these objects allowed asylum authorities to guide patients towards rational 
channels of thought and practice proper decorum, they also provided a valuable way of "occupying the mind to the exclusion of false notions and morbid feelings" (Galt I852: 28). This approach was not unusual. An I847 article written by Amariah Brigham, psychiatrist and editor of the Journal of American Insanity, encouraged incorporating the study of the natural sciences into the asylum regime. The "regular and rational employment of the mind" provided by this study, Brigham (I847: I2) argued, was particularly suitable as a curative mechanism for its ability to engage patients' attention and foster the "improvement of [their] mental and moral powers." A supply of "books, maps, apparatus illustrative of different sciences, and ... collections in natural history" would be required for these discussions, including examples to explain principles relating to chemistry, mineralogy, and conchology (ibid.).

At the Asylum, this collection may have offered a unique way to bring the out of doors indoors, as a therapeutic mechanism. The role was especially valuable at this institution precisely because it lacked grounds that were sufficiently large or developed enough to ensure that all patients had access to the curative benefits of nature. Archaeological and archival evidence suggests that Galt explicitly employed the fossilized whale vertebra recovered from the Asylum site as a mechanism of the moral management cure, and the substantial size of the object makes it unlikely that it was casually encountered on the grounds. Rather, this piece of natural history exemplifies the use of nature in moral management practice - as well as a somewhat makeshift solution to institutional shortcomings. Contrastingly, it seems increasingly likely that the remains of the sand dollar recovered from the Hospital dump were collected by a patient from the nearby beach. Meanwhile, the circumstances of its disposal in the dumpsite suggests that artifact was viewed as an inappropriate or undesirable addition to the institutional landscape. In this way, the sand dollar articulates a point of conflict between these meanings and constructions of nature as a therapeutic resource, and how the patients in their care related to it.

Rather than existing passively in a landscape intended for moving through, viewing, and interacting with institutionally-approved ways, patients also approached their 'curative' natural surroundings as a material resource. Many professionals acknowledged this tendency and worked to balance out this co-option without discouraging patients from their interests. Prominent British psychiatrist Charles Mercier suggested an approach that integrated patients' desire to engage with the natural world with the benefits of maintaining such curiosities. In his treatise, Lunatic Asylums, Their Organisation and Management, Mercier (I894: I9I) encouraged superintendents to retain interesting items that patients collected during their outdoor 
recreations. The asylum estate could yield an array of natural curiosities, he noted, from 'ancient' flint implements to birds' nests. "If preserved ... suitably described and labelled with the name of the contributors," Mercier observed, these objects could "afford gratification to [the patients who collected them] and arouse the emulation of others" (ibid.). By reframing patient activities in this way, potentially dangerous habits could thus be made to fit the needs and purposes of the institution.

Mercier's suggestion for mediating the juxtaposing ways in which patients and practitioners might relate to the natural world, however, does not appear to have been commonplace practice. Nellie Bly, author of Ten Days in a Madhouse - a published version of her exposé The Women's Lunatic Asylum on Blackwell Island, which she infiltrated as a reporter on behalf of the New York World in 1887 - identified a similar tension between institutional management and individualized patient treatment that was articulated through interactions with the natural world:

[Patients] are not allowed on the grass - it is only to look at. I saw some patients eagerly and caressingly lift a nut or a colored leaf that had fallen on the path. But they were not allowed to keep them. The nurses would always compel them to throw their little bit of God's comfort away. (Bly I887: 130)

Restrictions like these existed in tension with the curative ideals of moral management - at least, insofar as they were articulated in the literature. While the grounds were curative, boundaries had to be drawn between the interior and the grounds to ensure patients' and staff members' safety. A patient subculture of secreting articles into the hospital from the grounds created significant challenges to institutional efforts to maintain control over the material world on the wards. Meanwhile, 'natural' objects like the sand dollar may have been barred from the wards over sanitary concerns. As superintendent of the Pennsylvania Hospital for the Insane and co-founder of the Association for Medical Superintendents of American Institutions for the Insane Thomas Kirkbride (I854: 2I) advised, a well-built and run lunatic asylum harbored "[no] spot for foul air, or ... deposit of filth." Organic matter was subject to decay. To Kirkbride and his successors, 'filth' of this kind would have presented a threat to the physical health and emotional well-being of patients and their caretakers. This perception of danger, then, also motived the removal of natural or organic materials from the interior spaces of the institution. An untreated sand dollar picked off the shoreline would begin to decay and, invariably, start to smell. This unpleasant sensory marker would not only betray its presence on the 
ward but impel its disposal. If this object was intercepted and confiscated before entering the institution, its disposal is similarly telling. While amassing collections of bird nests and shells was discussed as bearing significance in the therapeutic process, preserving the sand dollar properly required time and resources that the institution was unwilling or unable to dedicate to its preservation. Thus, while the natural surroundings of the asylum were understood by its advocates to serve as a curative resource, patients could co-opt these landscapes - engaging with them as if they were a source of material culture, rather than a series of scenes and settings that could channel exercises and recreations that would benefit patients' state of mind. As both case studies highlight, then, the resources available to institutional authorities were often insufficient to ensure that the realities of the moral management cure matched up to its rhetorical ideals.

\section{Conclusions}

While the Eastern Lunatic Asylum and the Western Washington Hospital for the Insane operated in very different contexts, both institutions framed the treatment that they delivered in terms of the rhetoric of moral management. By integrating archaeological and historical research it becomes clear that patient and institutional realities often diverged from idealized natural encounters described in much of the formal literature. Dr. John Galt, Superintendent at the Asylum, curated a small collection of natural wonders to redirect patients' attention and give them an opportunity to practice rational thought and conversation. While there is no evidence that this unusual collection was a direct response to its insufficient estate and limited natural resources of the Asylum, its assemblage of natural history materials supplemented its curative role - relocating some of curative encounters from the sparse Asylum grounds and into the institution itself. Contrastingly, the Hospital possessed an estate that aligned more closely in terms of size and character; patients were able to participate in various occupations, chores, and recreations on its grounds. However, as the archaeological record attests, patients did not always view or interact with the natural world in the capacities that institutional authorities envisioned. The Hospital's patients were expected to take interest in viewing and moving through the grounds that surrounded them, and to benefit from the exercise and other outdoor activities it afforded them. However, this curative prac- 
tice was complicated by an institutional subculture of collecting objects that patients brought back onto the wards.

As Nancy Tomes (I984: vii) observes, life inside the I9th-century lunatic asylum was ultimately shaped by "all-too-human blend of medicine, morality and expediency." The financial and material limitations of the grounds and gardens of these institutions, combined with health and safety concerns, restricted the ideal forms of moral management practice espoused in a wealth of treatises, proceedings, and annual reports. Thus, by bringing conflicts between ideal and practice into focus, the human element of these complex institutional histories can be revealed.

The rhetoric of the moral management movement positions the natural world as a central curative force in asylum treatment. Asylum authorities believed that bringing patients into contact with the 'right' kind of natural landscapes in the 'correct' ways would channel patients' bodies and minds back towards physical and mental health. Scholars in several disciplines, from garden history to geography, have scrutinized the historical therapeutic role of the gardens, lawns, and sports fields that made up these institutional estates; however, the ongoing reliance on documentary sources alone means that the narratives produced are drawn largely from a singular, institutional perspective. The addition of novel, interdisciplinary perspectives adds nuance and depth to these historical landscapes, highlighting the tensions between ideal and practice. Historical archaeology, which brings together archival and archaeological data, makes the dissonances between the rhetorical ideals and the lived realities of asylum life increasingly clear. It is this dissonance between rhetoric and practice that re-humanizes the historic asylum. 


\section{Notes}

1

For further reading on archaeological approaches, methods, and theory, see Deetz (1977): Hall/Silliman (2006); Hicks/Beaudry (2006).

\section{2}

For further discussion of these challenges, see Condrau (2007); Swartz (2008); McCarthy et al. (2017).

\section{Sources}

Anonymous (1877): "Hospital for the Insane: Special Correspondence of the Standard, 4 July." Washington State Archives, Institutions Department, Western State Hospital, 1871-1979. Box 94.

Cooley, C. (1964): "The Western State Hospital, Fort Steilacoom, Washington, History 18711950." Washington State Archives, Institutions Department, Western State Hospital, 1871-1979. Box 126.

Galt, J. M. (1845): "The Annual Report of the Physician and Superintendent of the Eastern Asylum, in the city of Williamsburg, Virginia, for 1844." Richmond: Shepherd and Colin. Library of Virginia, Eastern State Hospital Collection. Box 74, Folder 8.

Galt, J. M. (1852): "The Annual Report of the Physician and Superintendent of the Eastern Asylum, in the city of Williamsburg, Virginia, for 1851." Library of Virginia, Eastern State Hospital Collection. Box 75, Folder 5.
Galt, J. M. (1854): "The Annual Report of the Physician and Superintendent of the Eastern Asylum, in the city of Williamsburg, Virginia, for 1853-4." Richmond: Ritchies \& Dunnavant. Library of Virginia, Eastern State Hospital Collection. Box 75, Folder 7.

Galt, S. M. (1863): "Dearest Miss Dix, You told me when you visited me in the summer..." Swem Library, College of William and Mary. Williamsburg, VA. Galt Family Papers I: Medical Papers. Box 3, Folder 34

Galt, S. M. (1869): "My Dear Miss Dix, One of the viscitudes experienced by my unhappy country..." Swem Library, College of William and Mary. Williamsburg, VA. Galt Family Papers I: Medical Papers. Box 3, Folder 34

Majetts, J. (1859): "To the superintendent of Either Lunatic Asylum, Va." Swem Library, College of William and Mary. Williamsburg, VA. John Minson Galt Papers II: Medical Papers. Box 78, Folder 165.

Myzk, W. R. (1983): "Draft Final Report Public Hospital Excavation October 1981-January 1983." Office of Excavation and Conservation, Department of Archaeology, Colonial Williamsburg Foundation.

Semple, J. (1908): "Eastern Washington Hospital for the Insane, Medical Lake: Superintendent's Report." In: Fourth Bienniel Report of the State Board of Control for the Term Beginning October 1, 1906 and Ending September 20, 1908. Olympia, Washington: C.W. Gorman, Public Printer. Washington State Archives, Institutions Department, Western State Hospital, 1871-1979. Box 1. Waughop, J. W. (1887): "Report of the Superintendent." Olympia, Washington: C.B. Bagley, Public Printer. Washington State Archives, Institutions Department, Western State Hospital, 1871-1979. Box 9.

Waughop, J. W. (1894): "Report of the Superintendent, Hospital for the Insane, 1893-4." Olympia, Washington: O.C. White, State Printer. Washington State Archives, Institutions Department, Western State Hospital, 1871-1979. Box 1. 


\section{Bibliography}

Allman, Skye/Rubio, Sina (2013): Dendraster excentricus, Animal Diversity Web, http://animaldiversity.org/accounts/Dendraster_excentricus, accessed January 8, 2018.

Association of Medical Superintendents of American Institutions for the Insane (1885): History of the Association of Medical Superintendents of American Institutions for the Insane, from I844 to I884, Inclusive, edited by J. Curwen, Warren, Pennsylvania: E. Cowan \& Co. printers, https://hdl. handle.net/2027/chi.41668591, accessed August 4, 2017.

Bly, Nelly (1887): Ten Days in a Mad-House, New York: Munro.

Brigham, Amariah (1847): "The moral treatment of insanity." In: American Journal of Psychiatry 4/1, pp. 1-15.

Callard, Felicity/Fitzgerald, Des/Woods, Angela (2015): "Interdisciplinary collaboration in action: Tracking the signal, tracing the noise." In: Palgrave Communications 1, pp. 1-7.

Cherry, Steven/Munting, Roger (2005): “Exercise is the Thing'? Sport and the Asylum c. 1850-1950." In: The International Journal of the History of Sport 22/1, pp. 42-58.

Condrau, Flurin (2007): "The patient's view meets the clinical gaze." In: Social History of Medicine 20/3, pp. 525-540.

D'Agostino, M. E. (ed.) (1995): The Written and the Wrought: Complementary Sources in Historical Anthropology: Essays in Honor of James Deetz, Berkeley: Kroeber Anthropological Society. Dain, Norman (1971): Disordered Minds: The First Century of Eastern State Hospital in Williamsburg, Virginia, I766-I866, Williamsburg: Colonial Williamsburg Foundation.

Deetz, James (1977): In Small Things Forgotten: The Archaeology of Everyday Life in Early America, New York: Anchor Books.

Dunglison, Robley (1836): General therapeutics, or Principles of medical practice: with tables of the chief remedial agents and their preparations and of the different poisons and their antidotes Philadelphia: Carey, Lea, and Blanchard.

Eastoe, Stef (2016): "'Relieving gloomy and objectless lives.' The landscape of Caterham Imbecile Asylum." In: Landscape Research 41/6, pp. 652-663.

Eghigian, Greg (2011): "Deinstitutionalizing the history of contemporary psychiatry." In: History of Psychiatry 22/2, pp. 201-214

Garland, D. (ed.) (1835): "[Doc No. 36] Report of the Committee Appointed to Examine the State and Condition of the Lunatic Hospital at Williamsburg." In: Journal of the House of Delegates of Virginia, pp. 1-9.

Gesler, Wilbert (2005): "Therapeutic landscapes: an evolving theme." In: Health \& Place 11/4, pp. 295-297.

Goldsmith, M./Reed, A. (1912): Report of Conditions in the State Institutions of Washington Together with Recommendations for Needed Changes in Administration and Legislation, Olympia: E.L. Boardman, Public Printer.

Hall, Martin/Silliman, Stephen W. (2006): Historical Archaeology, Malden: Blackwell.

Hickman, Clare (2005): "The Picturesque at Brislington House, Bristol: The Role of Landscape in Relation to the Treatment of Mental Illness in the Early Nineteenth-Century Asylum." In: Garden History 33/1, pp. 47-60.

Hickman, Clare (2009): "Cheerful prospects and tranquil restoration: the visual experience of landscape as part of the therapeutic regime of the British asylum, 1800-60." In: History of Psychiatry 20/4, pp. 425-41.

Hickman, Clare (2013): Therapeutic Landscapes: A History of English Hospital Gardens since I80o Manchester: Manchester University Press.

Hicks, Dan/Beaudry, Mary (eds.) (2006): The Cambridge Companion to Historical Archaeology, Cambridge: Cambridge University Press.

Hollander, Russell (1982): "Life at the Washington Asylum for the Insane, 1871-1880." In: Historian 44/2, pp. 229-241.

Hume, Ivor Noel (1996): In Search of This \& That: Tales from an Archaeologist's Quest, Williamsburg: Colonial Williamsburg Foundation. 
Jovilette, Stephanie et al. (2016): Archaeological Monitoring for the Western State Hospital Fenceline Installation Project and Testing of a Late-Nineteenth-Century Institutional Trash Deposit, Site 45PII05, Fort Steilacoom Historic District, Pierce County, Washington, Washington: Statistical Research Inc.

Kelly, Brendan D. (2016): "Searching for the patient's voice in the lrish asylums." In: Medical Humanities 42/2, pp. 1-5.

Kirkbride, Thomas Story (1854): On the Construction, Organization, and General Arrangements of Hospitals for the Insane, New York: Arno Press.

Lattin, Frank H. (1889): The Oölogist: For the Student of Birds, Their Nests and Eggs, Albion, N.Y.: Frank H. Lattin.

Longhurst, Peta (2015): "Institutional non-correspondence: Materiality and ideology in the mental institutions of New South Wales." In: Post-Medieval Archaeology 49/2, pp. 220-237.

McCarthy, Angela et al. (2017): "Lives in the Asylum Record, 1864 to 1910: Utilising Large Data Collection for Histories of Psychiatry and Mental Health." In: Medical History 61/3, pp. 358-379. Mercier, Charles A. (1894): Lunatic Asylums: Their Organisation and Management, London: Griffin.

Merrill, L. Lynn (1989): The Romance of Victorian Natural History, Oxford: Oxford University Press.

Philo, Chris (2004): A Geographical History of Institutional Provision for the Insane from Medieval Times to the I860's in England and Wales, Lewiston: Edwin Mellen Press.

Piddock, Susan (2007): A Space of Their Own: The Archaeology of Nineteenth Century Lunatic Asylums in Britain, South Australia and Tasmania, New York: Springer.

Piddock, Susan (2009): "John Conolly's 'Ideal' asylum and provisions for the insane in nineteenth century South Australia and Tasmania." In: Beisaw, April M./Gibb, James G. (eds.): The Archaeology of Institutional Life, New York: Springer, pp. 187-205.
Porter, Roy (1985): "The Patient's View: Doing Medical History from below." In: Theory and Society 14/2, pp. 175-198.

Rutherford, Sarah (2003): The Landscapes of Public Lunatic Asylums in England, I808-19I4, PhD thesis, Leicester: De Montfort University, https://www.dora.dmu.ac.uk/handle/2086/4783, accessed December 1, 2019

Rutherford, Sarah (2005): "Landscapers for the Mind: English Asylum Designers, 1845-1914." In: Garden History 33/1 pp. 61-86.

Scott, Elizabeth M. (1994): Those of Little Note: Gender, Race, and Class in Historical Archaeology, Tuzcon: University of Arizona Press.

Swartz, Sally (2008): "Colonial lunatic asylum archives: Challenges to historiography." In: Kronos 34/1, pp. 285-302.

Tomes, Nancy (1984); A Generous Confidence: Thomas Story Kirkbride and the Art of AsylumKeeping, 1840-I883, Cambridge: Cambridge University Press.

Webb, W. F. (1895): The Museum: A Journal Devoted to Research in Natural Science, Albion, New York: W.F. Webb. Hathi Trust Digital Library. Weimerskirch, Philip. J. (1965): "Benjamin Rush and John Minson Galt, II: Pioneers of Bibliotherapy in America." In: Bulletin of the Medical Library Association 54/4, pp. 510-526.

Whittemore, M. E. (1885): "Sand Dollars and Sea Eggs.” In: Vick's Monthly Magazine 8, pp. 192.

Wickham, Blaine (2016): Into the Void: A Crossborder Comparison of the Mental Asylum on the American and Canadian Frontier, dissertation, University of Saskatchewan: Saskatoon, https:// harvest.usask.ca/handle/10388/7648, accessed August 20, 2020.

Wylie, Alison (1989): "Archaeological Cables and Tacking: The Implications of Practice for Bernstein's 'Options Beyond Objectivism and Relativism.' In: Philosophy of the Social Sciences 19/1, pp. 1-18. Zwelling, Shomer S. (1985): Quest for a Cure: The Public Hospital in Williamsburg, I773-I885, Williamsburg: Colonial Williamsburg Foundation. 